\title{
Machine learning techniques for optical communication system optimization
}

\author{
Zibar, Darko; Wass, Jesper; Thrane, Jakob; Piels, Molly
}

Link to article, DOI:

10.1109/ICTON.2017.8025039

Publication date:

2017

Document Version

Publisher's PDF, also known as Version of record

Link back to DTU Orbit

Citation (APA):

Zibar, D., Wass, J., Thrane, J., \& Piels, M. (2017). Machine learning techniques for optical communication system optimization. Abstract from 19th International Conference on Transparent Optical Networks, Girona, Spain. https://doi.org/10.1109/ICTON.2017.8025039

\section{General rights}

Copyright and moral rights for the publications made accessible in the public portal are retained by the authors and/or other copyright owners and it is a condition of accessing publications that users recognise and abide by the legal requirements associated with these rights.

- Users may download and print one copy of any publication from the public portal for the purpose of private study or research.

- You may not further distribute the material or use it for any profit-making activity or commercial gain

- You may freely distribute the URL identifying the publication in the public portal

If you believe that this document breaches copyright please contact us providing details, and we will remove access to the work immediately and investigate your claim. 


\title{
Machine Learning Techniques for Optical Communication System Optimization
}

\author{
Darko Zibar, Jesper Wass, Jakob Thrane, and Molly Piels \\ DTU Fotonik, Lyngby, Denmark
}

\section{ABSTRACT}

In this paper, machine learning techniques relevant to optical communication are presented and discussed. The focus is on applying machine learning tools to optical performance monitoring and performance prediction. 